\title{
THE SITE OF THE ACTIVITY OF EXTRACELLULAR PRODUCTS OF PSEUDOMONAS AERUGINOSA IN THE ELECTRON-TRANSPORT CHAIN IN MAMMALIAN CELL RESPIRATION
}

\author{
AnN V. Armstrong and D. E. S. Stewart-Tull \\ Microbiology Department, Alexander Stone Building, Glasgow University, \\ Garscube Estate, Bearsden, Glasgow
}

IN a previous communication Armstrong, Stewart-Tull and Roberts (1971) found that 1-hydroxyphenazine inhibited the uptake of oxygen by mouse-liver mitochondria.

The 1-hydroxyphenazine was either chemically synthesised or prepared from a biological sample of pyocyanin obtained previously from the culture filtrate of Pseudomonas aeruginosa NCTC6750. The inhibition was not significant with pyrogallol monomethylether, 1-methoxyphenazine or pyocyanin. Although numerous lines of research were followed for many years the exact mode of action of pyocyanin and its phenazine derivatives on cellular respiration has not been determined. Pyocyanin has been described as an electron donor and acceptor, a terminal oxidase and an inhibitor, all of these functions taking place at different sites along the chain (Keilin and Hartree, 1940; Anderson, 1946; Hewitt, 1950; Mahler and Cordes, 1968). Lightbown and Jackson (1956) isolated 2-alkyl-4-hydroxyquinoline-Noxides from Ps. aeruginosa and showed that they were potent inhibitors of succinic oxidase acting between cytochrome $b$ and $c$ in the electron-transport chain.

The purpose of the present investigation was to determine the site of activity in the electron-transport chain of 1-hydroxyphenazine, derived from $P s$. aeruginosa or chemically synthesised.

\section{MATERIALS AND METHODS}

Pseudomonas fractions and mouse-liver mitochondrial suspensions. These were prepared according to the methods outlined by Armstrong et al.

The effect of pseudomonas fractions at the site of succinic dehydrogenase. Thunberg tubes were set up containing $1.4 \mathrm{ml}$ Hendry's sucrose phosphate buffer (I), $0.5 \mathrm{ml}$ mouseliver mitochondrial suspension, $0.5 \mathrm{ml}$ pseudomonas fraction in the tube and $0.3 \mathrm{ml} 0.2 \mathrm{M}$ sodium succinate plus $0.3 \mathrm{ml} 0.001 \mathrm{M}$ methylene blue in the side-arm; controls were set up without a pseudomonas fraction. After equilibration to $37^{\circ} \mathrm{C}$ the contents of the side-arm were tipped into the evacuated tube and the time required for 90 per cent. reduction of the dye was taken as a measure of dehydrogenase activity.

The effect of pseudomonas fractions at the site of cytochrome oxidase. This was measured manometrically in the Warburg apparatus by the standard method described by Armstrong et al., with the exception that paraphenylenediamine (16.24 $\mathrm{mg}$ per $\mathrm{ml}$ buffer I) or $0.2 \mathrm{M}$ sodium succinate was the substrate. To further investigate any activity at this site $0.3 \mathrm{ml}$ cytochrome $c(2.4 \mathrm{mg}$ per $\mathrm{ml}$ buffer I; Koch-Light Laboratories Ltd) was added from the second side-arm to mitochondria respiring on sodium succinate and treated with a pseudomonas fraction. 
The effect of pseudomonas fraction at the site of coenzyme $Q$ (ubiquinone)-cytochrome $b$. (i) In a series of standard Warburg experiments $0.5 \mathrm{ml}$ mouse-liver mitochondrial suspension,

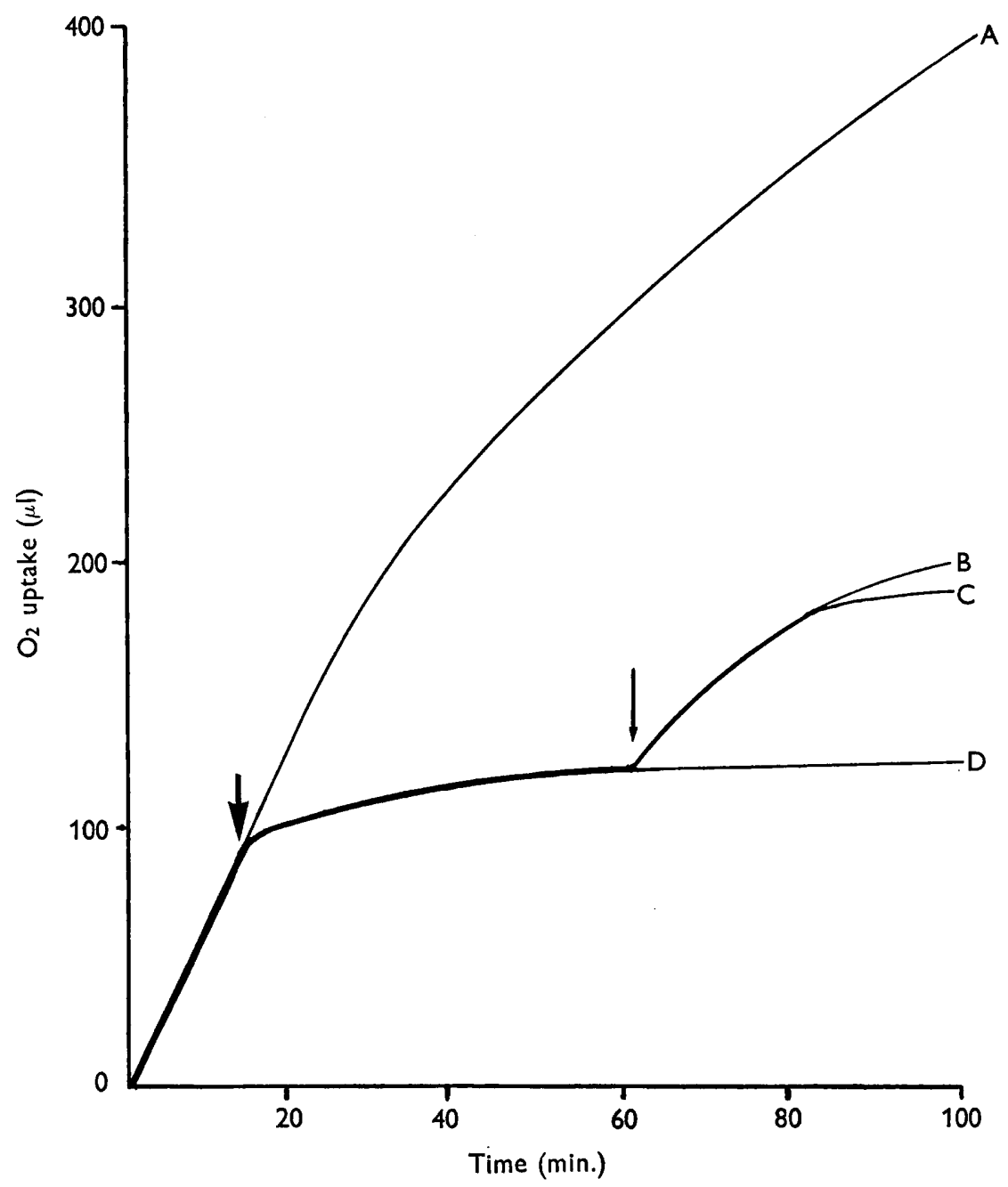

Fig. 1.-The effect of pseudomonas fractions at the site of ubiquinone in the electron-transport chain. A-control Warburg flask or control plus ubiquinone; $B$ and $C$-flasks containing fractions PF2 or PF43, respectively, together with ubiquinone; $D$-flasks containing PF2 or PF43 but without ubiquinone. PF2, a crude fraction containing 1-hydroxyphenazine prepared from $P$ s. aeruginosa culture fluid. PF43, 1-hydroxyphenazine prepared from a biological sample of pyocyanin. The pseudomonas fractions were tipped after $15 \mathrm{~min}$., largeheaded arrow; ubiquinone was tipped after 60 min., small-headed arrow.

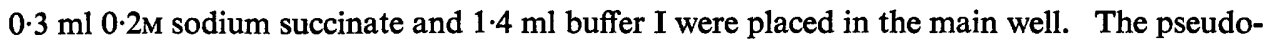
monas fraction $(0.5 \mathrm{ml})$ and $0.3 \mathrm{ml}$ ubiquinone $\left(100 \mu \mathrm{g}\right.$ per $\mathrm{ml} ; Q_{10}$ ex beef heart mitochondria: Koch-Light Laboratories Ltd) were placed in side-arms 1 and 2 respectively. The pseudomonas fraction was tipped into the main well after $15 \mathrm{~min}$. and ubiquinone after $60 \mathrm{~min}$. The ubiquinone stock solution was prepared by dissolving $10 \mathrm{mg}$ in $1 \mathrm{ml}$ ethanol; this solution was diluted with buffer I to give the required concentration. 
Attempts were made to protect mitochondria by adding $0.3 \mathrm{ml}$ ubiquinone $(100 \mu \mathrm{g}$ per $\mathrm{ml}$ ) into the main well before the addition of the pseudomonas fraction.

(ii) The effect of 1-hydroxyphenazine preparations was also examined in the oxygen polarograph. In all experiments $0.3 \mathrm{ml} 0 \cdot 2 \mathrm{M}$ sodium succinate and $0.1 \mathrm{ml}$ mouse-liver mitochondrial suspension were placed in the sample chamber. Different concentrations of 1-hydroxyphenazine were tested for their activity before and after the addition of ubiquinone; the total volume in each test was adjusted to $3 \mathrm{ml}$ with Hendry's sucrose phosphate buffer, $p \mathbf{H} 7 \cdot 3$.

\section{RESULTS}

Succinic dehydrogenase site

A 90 per cent. reduction of methylene blue was observed in both the test and control Thunberg tubes after $15 \mathrm{~min}$.

\section{Cytochrome oxidase site}

The oxygen uptake by mitochondria utilising succinate was 5-10 $\mu 1$ in $75 \mathrm{~min}$. in the presence of active pseudomonas fractions, whereas in the control flasks the uptake was $230 \mu 1$ in $75 \mathrm{~min}$. The addition of cytochrome $c$ to the treated mitochondria did not cause a recovery of respiration.

However, mitochondria utilising paraphenylenediamine, which enters at the site of cytochrome $c$, were not inhibited by any pseudomonas fraction. The oxygen uptake by treated mitochondria was $190 \mu \mathrm{l}$ in $75 \mathrm{~min}$. and by untreated mitochondria $198 \mu \mathrm{l}$ in $75 \mathrm{~min}$.

\section{Ubiquinone-cytochrome b site}

(i) Warburg manometry. As shown in fig. 1-D, the pseudomonas fractions containing 1-hydroxyphenazine PF2 and PF43 inhibited the uptake of oxygen when tipped on to respiring mitochondria $15 \mathrm{~min}$. after equilibration time. In a duplicate experiment, when ubiquinone was added from a second side-arm after $60 \mathrm{~min}$. the rate of oxygen uptake was restored (fig. 1-B and C) to a level comparable with the uptake in the control flasks (fig. 1-A); this restoration lasted only $20 \mathrm{~min}$.

Attempts to protect mitochondria by adding $100 \mu \mathrm{g}$ ubiquinone per $\mathrm{ml}$ $15 \mathrm{~min}$. before the pseudomonas fractions were inconclusive. A three-fold increase in oxygen uptake, from $10 \mu \mathrm{l}$ to $30 \mu \mathrm{l}$ was observed after $80 \mathrm{~min}$.; the oxygen uptake in the control flasks was, however, $310 \mu 1$ after the same time.

(ii) Polarograph technique. The results shown in the table indicate that 1-hydroxyphenazine completely inhibited the uptake of oxygen by mouse-liver mitochondria. The addition of ubiquinone $3 \mathrm{~min}$. after the 1-hydroxyphenazine restored oxygen uptake by 3-6 per cent. only, and it was apparent that this effect was not dependent on the concentration of ubiquinone. On the other hand, the addition of $100 \mu \mathrm{g}$ ubiquinone per $\mathrm{ml}$ to mouse-liver mitochondria $2 \mathrm{~min}$. before the addition of $33 \mu \mathrm{g} 1$-hydroxyphenazine per $\mathrm{ml}$ reduced the inhibitory activity of the latter compound (fig. 2). 


\section{DisCUSSION}

Inhibition of mouse-liver mitochondrial respiration was shown by Armstrong et al. (1971) to occur immediately after the addition of 1-hydroxyphenazine. This suggested that an immediate block in the electron-transport chain or an " electron shunt" was produced. Results in this paper indicate that 1-hydroxyphenazine causes no inhibition at the site of succinic dehydrogenase in the

TABLE

The effect of 1-hydroxyphenazine on mitochondrial respiration before and after the addition of ubiquinone

\begin{tabular}{|c|c|c|c|c|c|c|}
\hline \multirow{2}{*}{$\begin{array}{c}\text { Order } \\
\text { of addition } \\
\text { of substances }\end{array}$} & \multirow{2}{*}{\multicolumn{3}{|c|}{ Substance }} & \multirow{2}{*}{$\begin{array}{c}\text { Amount } \\
\text { of substance } \\
\text { added }(\mu \mathrm{g})\end{array}$} & \multicolumn{2}{|c|}{$\begin{array}{l}\mu 1 \mathrm{O}_{2} \text { consumed per } 0.5 \mathrm{ml} \text { mito- } \\
\text { chondrial suspension per min. }\end{array}$} \\
\hline & & & & & $\begin{array}{c}\text { before } \\
\text { addition of } \\
\text { substance }\end{array}$ & $\begin{array}{l}\text { after } \\
\text { addition of } \\
\text { substance }\end{array}$ \\
\hline$\frac{1}{2}$ & $\begin{array}{l}\text { PF43* } \\
\text { Ubiquinone }\end{array}$ & $\dot{.}$ & $: \quad:$ & $\begin{array}{r}16 \\
100\end{array}$ & $\begin{array}{l}6 \cdot 6 \\
0\end{array}$ & $\begin{array}{l}0 \\
0 \cdot 15\end{array}$ \\
\hline $\begin{array}{l}1 \\
2\end{array}$ & $\begin{array}{l}\text { PF43 . } \\
\text { Ubiquinone }\end{array}$ & $\dot{.}$ & $: \quad:$ & $\begin{array}{l}25 \\
33\end{array}$ & $\begin{array}{l}5 \cdot 5 \\
0\end{array}$ & $\begin{array}{l}0 \\
0 \cdot 3\end{array}$ \\
\hline$\frac{1}{2}$ & $\begin{array}{l}\text { PF43 . } \\
\text { Ubiquinone }\end{array}$ & . & 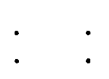 & $\begin{array}{l}33 \\
33\end{array}$ & $\begin{array}{l}6 \cdot 5 \\
0\end{array}$ & $\begin{array}{l}0 \\
0 \cdot 15\end{array}$ \\
\hline $\begin{array}{l}1 \\
2\end{array}$ & $\begin{array}{l}\text { PF48† } \\
\text { Ubiquinone }\end{array}$ & . & $: \quad:$ & $\begin{array}{l}25 \\
33\end{array}$ & $\begin{array}{l}4 \cdot 5 \\
0\end{array}$ & $\begin{array}{l}0 \\
0 \cdot 3\end{array}$ \\
\hline $\begin{array}{l}1 \\
2\end{array}$ & $\begin{array}{l}\text { PF48 } \\
\text { Ubiquinone }\end{array}$ & $\dot{s}$ & $\cdot \quad:$ & $\begin{array}{l}33 \\
33\end{array}$ & $\begin{array}{l}4 \cdot 75 \\
0\end{array}$ & $\begin{array}{l}0 \\
0 \cdot 15\end{array}$ \\
\hline
\end{tabular}

* PF43 = 1-hydroxyphenazine prepared from biological pyocyanin (PF42).

$\uparrow$ PF48 $=$ chemically synthesised 1 -hydroxphenazine.

electron-transport chain. Similarly, when mouse-liver mitochondria utilised paraphenylenediamine as substrate no inhibition of respiration was observed. Slater (1949) showed that mouse-liver mitochondria oxidise paraphenylenediamine, which enters the electron-transport chain at the site of cytochrome $c$. Therefore, it is reasonable to assume that the block caused by 1-hydroxyphenazine occurred at a site prior to cytochrome $c$ in the chain. Indeed, when ubiquinone (Coenzyme $Q$ ) was added to mouse-liver mitochondria inhibited by 1-hydroxyphenazine, the rate of oxygen uptake was restored to a level comparable with that of controls (fig. 1). In addition, when ubiquinone was added to mouse-liver mitochondria before exposure to 1-hydroxyphenazine the rate of oxygen uptake was greater than that found in reactions with mitochondria not 
protected with ubiquinone (fig. 2). These results indicate that 1-hydroxyphenazine, derived from culture filtrates of $P$ s. aeruginosa, inhibits mouse-liver

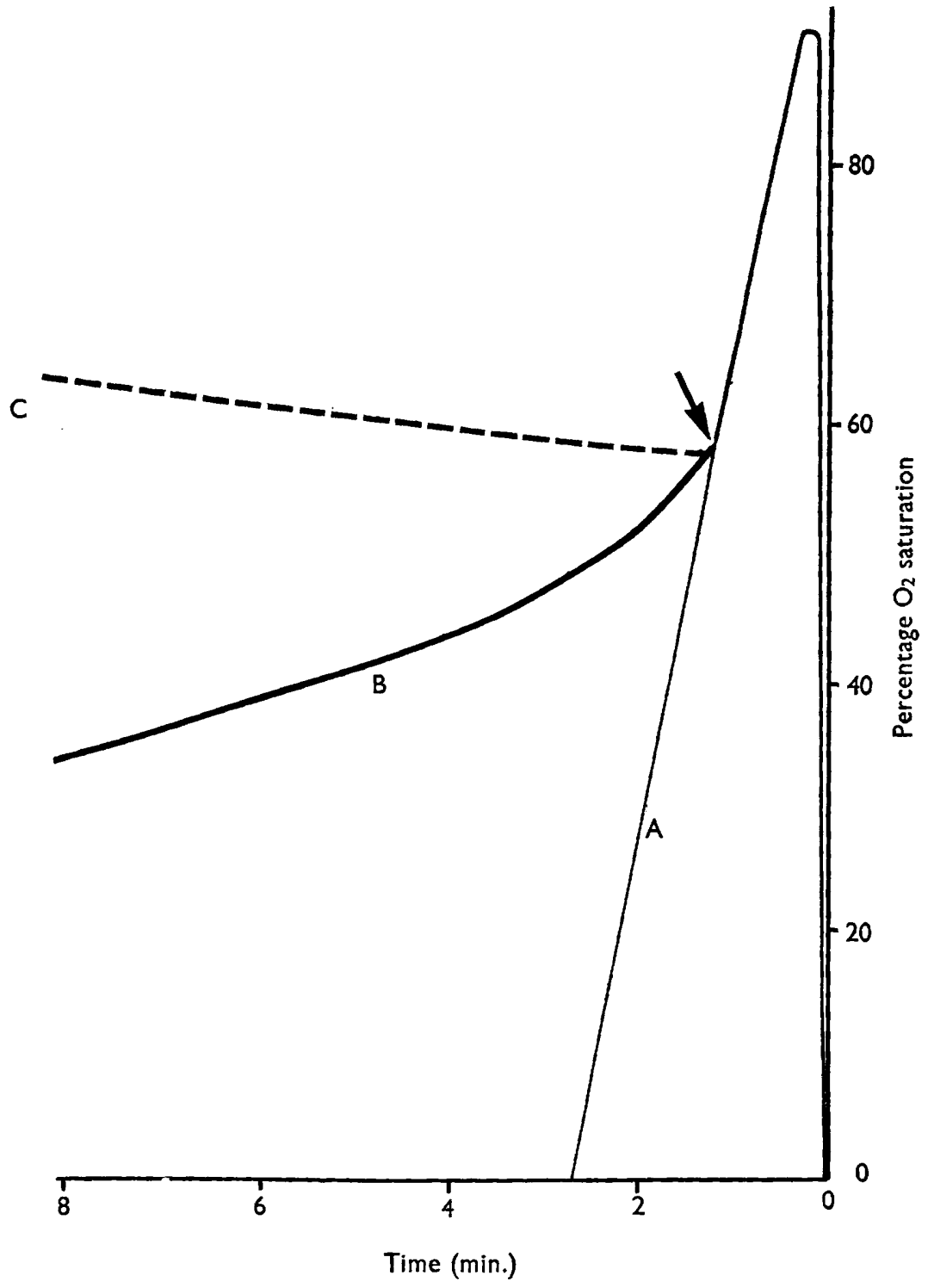

Fig. 2.-The effect of 1-hydroxyphenazine on the respiration of mouse-liver mitochondria, in the presence and absence of ubiquinone, measured in the oxygen polarograph. Uptake of oxygen by $\mathrm{A}$, control mitochondria, B, mitochondria pretreated with $100 \mu \mathrm{g}$ per ml ubiquinone and subsequently treated with $33 \mu \mathrm{g}$ per $\mathrm{ml} 1$-hydroxyphenazine, and $\mathrm{C}$, mitochondria treated with 1-hydroxyphenazine. The 1-hydroxyphenazine was added at the point marked with an arrow.

mitochondrial respiration at a site corresponding to ubiquinone (Co $\mathrm{Q}$ ) or Co Q-cytochrome $b$ in the electron-transport chain (fig. 3).

Some phenazines because of their semi-reduced state can act as transfer 
agents or electron-carriers for oxygen in the metabolic processes of biological systems. It is possible that 1-hydroxyphenazine might act as an "electron shunt" at the site of ubiquinone-cytochrome $b$ by accepting electrons from complexes I and II and transporting them to a " dead end " unable to transfer them to cytochrome $c$ and the rest of the chain (fig. 3). Since ubiquinone and 1-hydroxyphenazine compete for the same site in the electron-transport chain it would be expected that the relative concentrations of these compounds would be important. It was found that a relatively large amount of ubiquinone $(100 \mu \mathrm{g}$ per $\mathrm{ml})$ was required to reduce the inhibitory effect of $33 \mu \mathrm{g}$ 1-hydroxyphenazine per $\mathrm{ml}$, which might suggest that the latter was more active in competing for the site on the electron-transport chain.

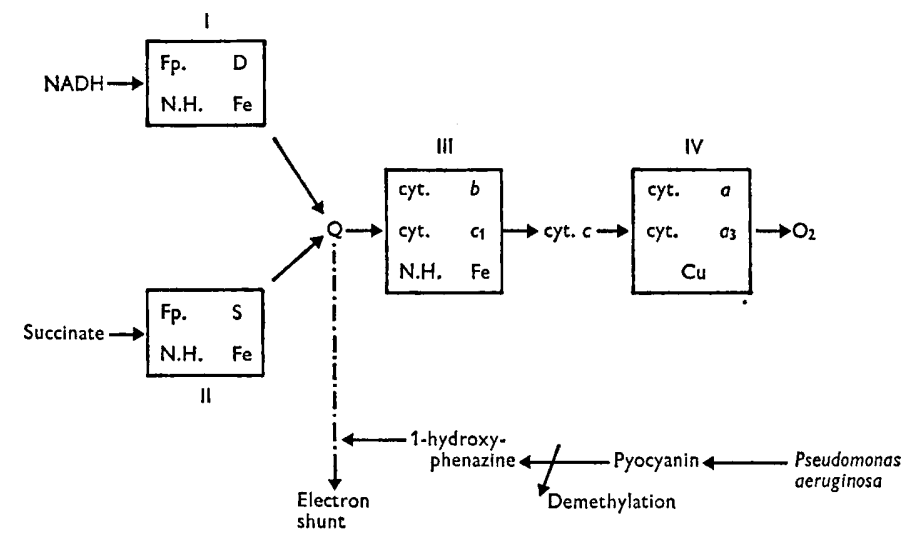

FIG. 3.-Schematic representation of the arrangement of the complexes in the mitochondrial electron-transport chain and the site of activity of 1-hydroxyphenazine. Fp. D denotes NADH dehydrogenase; Fp. S, succinic dehydrogenase; N.H. Fe, non-haem iron; I, NADH-Q reductase; II succinate-Q reductase; III Q-cytochrome $c$ reductase; IV cytochrome $c$ oxidase.

Various extracellular products of bacteria have been shown to impair mitochondrial respiration both in vitro and in vivo. A comparison of the sites of activity of these bacterial products in the electron-transport chain reveals that there is a fair degree of similarity in their modes of action. The alphatoxin of Clostridium welchii, identified as a phospholipase $\mathrm{C}$, was found to cause chemical changes in liver cell mitochondria accompanied by a marked decrease in succinic oxidase enzyme activity; this effect was thought to be due to inhibition in the electron-transport chain between cytochrome $b$ and cytochrome $c$ (Edwards and Ball, 1954; Macfarlane and Datta, 1954).

Chaudhuri and Martin (1953) showed that the succinate-neotetrazolium chloride reductase activity in the kidneys was less in animals infected with Mycobacterium tuberculosis. Kato et al. $(1958,1959)$ showed that cord factor inhibited the reduction of tetrazolium salt by a mouse-liver homogenate in the presence of various substrates; Kato (1966) suggested that cord factor acted at the point between cytochrome $c$ and cytochrome $a$.

The extracellular NAD-ase of Streptococcus pyogenes inhibited the oxidation of Krebs-cycle intermediates by mitochondria (Carlson et al., 1957) and 
cleaved the nicotinamide-ribose linkage of nicotinamide adenine dinucleotide. Swartz, Kaplan and Frech (1956) described NAD-ases from Proteus vulgaris and Bacillus subtilis that attacked the pyrophosphate group of NAD.

Investigation of the murine toxin of Pasteurella pestis revealed that the impairment of mitochondrial respiration was due to the action of the toxin on the electron-transport chain between $\mathrm{NADH}_{2}$ or succinate and cytochrome $b$, and more specifically at the level of $\mathrm{NADH}_{2}$-ubiquinone reductase (Ajl, Woebke and Rust, 1958; Kadis, Cohen and Ajl, 1965; Kadis, Montie and Aj1, 1966).

Neufeld, Coleman and Zannucci (1963) isolated an inhibitor from Serratia marcescens that had an action similar to that of the 2-alkyl-4-hydroxyquinoline$\mathrm{N}$-oxides isolated from Ps. aeruginosa. Lominski, Gemmell and Arbuthnott (1968) showed that mitochondrial respiration was impaired by a toxic complex from staphylococci that consisted of at least two components. One of these was found to impair electron transfer in the region of ubiquinone. It was suggested that the components of the complex were enzymic, acting on the phospholipids responsible for the integrity of the electron-transport chain. Although Armstrong et al. showed that 1-hydroxyphenazine was non-enzymic, it is interesting to postulate that pyocyanin produced by $P$ s. aeruginosa is a protoxic substance that is activated by the action of a demethylase, either derived from the host or from the organism itself, to yield the inhibitory 1-hydroxyphenazine.

Although this investigation has elucidated part of the pathogenic mechanism of Ps. aeruginosa at the molecular level, it is necessary to study further the activity of 1-hydroxyphenazine against whole cells both in vitro and in vivo, since there is as yet no evidence that 1-hydroxyphenazine passes through intact cell membranes.

\section{SUMMARY}

Since 1-hydroxyphenazine derived from Pseudomonas aeruginosa or chemically synthesised inhibited the uptake of oxygen by mouse liver mitochondria utilising sodium succinate, attempts were made to determine the site of activity in the electron transport chain. It was found that inhibition occurred at a site corresponding to ubiquinone (coenzyme Q) or Co Q-cytochrome $b$; the 1hydroxyphenazine might act as an "electron shunt" by accepting electrons and transporting them to a " dead end".

\section{REFERENCES}

AJL, S. J., WoEbKe, J., AND Rust, J., JR 1958. Inhibition of keto acid oxidation by plague toxin. J. Bact., 75, 449.

ANDERSon, C. G. 1946. An introduction to bacteriological chemistry, 2nd ed., Edinburgh, p. 177.

Armstrong, Ann V., Stewart-Tull, D. E. S., AND Roberts, J. S. 1971. Characterisation of the Pseudomonas aeruginosa factor that inhibits mouse-liver mitochondrial respiration. J. Med. Microbiol., 4, 249. 
Carlson, A. S., Kellner, A., Bernheimer, A. W., and Freeman, Elizabeth B. 1957. A streptococcal enzyme that acts specifically upon diphosphopyridine nucleotide: characterization of the enzyme and its separation from streptolysin O. J. Exp. Med., $106,15$.

Chaudhuri, S. N., AND Martin, S. P. 1953. Effect of infection with $M$. tuberculosis and of tuberculin shock on the succinic dehydrogenase activity of guinea pig tissues. $J$. Exp. Med., 98, 99.

Edwards, SAlly W., AND Ball, E. G. 1954. The action of phospholipases on succinate oxidase and cytochrome oxidase. J. Biol. Chem., 209, 619.

HewitT, L. F. 1950. Oxidation-reduction potentials in bacteriology and biochemistry, 6th ed., Edinburgh.

KADIs, S., CoHEN, M., AND AJL, S. J. 1965. The effect of plague murine toxin on the electron transport system. Biochim. biophys. Acta, 96, 179.

Kadis, S., MontIE, T. C., AND AJ, S. J. 1966. The murine toxin of Pasteurella pestis: a study in its development. Bact. Rev., 30, 177.

KATO, M. 1966. Studies on the biochemical lesion in experimental tuberculosis in mice. I. Effect of cord factor on the succinate-neotetrazolium reductase system. Amer. Rev. Resp. Dis., 93, 411.

Kato, M., Kusunose, M., Miki, K., Matsunaga, K., and Yamamura, Y. 1959. The mechanism of the toxicity of cord factor. Amer. Rev. Resp. Dis., 80, 240.

Kato, M., Miki, K., Matsunaga, K., and Yamamura, Y. 1958. Biologic and biochemical activities of "cord factor". With special reference to its role in the virulence of tubercle bacilli. Amer. Rev. Tuberc. Pulm. Dis., 77, 482.

Keilin, D., AND HARTREe, E. F. 1940. Succinic dehydrogenase-cytochrome system of cells. Intracellular respiratory system catalysing aerobic oxidation of succinic acid. Proc. Roy. Soc. B, 129, 277.

LightBown, J. W., AND JACKSON, F. L. 1956. Inhibition of cytochrome systems of heart muscle and certain bacteria by the antagonists of dihydrostreptomycin: 2-alkyl-4hydroxyquinoline $N$-oxides. Biochem. $J ., 63,130$.

Lominski, I., Gemmell, C. G., AND ARBUthNotT, J. P. 1968. A staphylococcal toxic complex affecting particular areas of the mitochondrial electron transport system. J. Gen. Microbiol., 52, 107.

Macfarlane, Marjorie G., and Datta, NAOMi 1954. Observations on the immunological and biochemical properties of liver mitochondria with reference to the action of Clostridium welchii toxin. Br. J. Exp. Path., 35, 191.

MAHLER, H. R., AND CORDES, E. H. 1968. Basic biological chemistry, London, p. 364.

Neufeld, H. A., Coleman, R. L., AND ZannuCCI, J. S. 1963. Respiratory inhibitor from Serratia marcescens. J. Bact., 85, 614.

Slater, E. C. 1949. The measurement of the cytochrome oxidase activity of enzyme preparations. Biochem. J., 44, 305.

Swartz, M. N., Kaplan, N. O., AND Frech, MARY E. 1956. Significance of "heatactivated" enzymes. Science, N.Y., 123, 50. 